\title{
Preface
}

\section{Plugging the Gaps}

$\mathrm{T}$

HIS BOOK IS ALL ABOUT GAPS. THE TRANSITION BETWEEN land and sea reveals governance and capacity deficits that challenge even the most well resourced countries. And those disconnects, which include legal and institutional ambiguities, grow larger with distance from the beach. No government can confront the political and operational issues found in the maritime domain without substantial assistance from its neighbors. A storm at sea is a compelling image that haunts maritime security officials everywhere. Calm water is frequently difficult to find. The book you are about to read attempts to help them locate it.

The Center for Civil-Military Relations (CCMR) at the Naval Postgraduate School published a book in 2011 on the threat from terrorism and government responses to it (Fighting Back: What Governments Can Do About Terrorism, Stanford University Press). Since that time, we have come to believe that a second volume focused on the maritime aspects of terrorism and other maritime threats - a sequel, if you will — could add value to our efforts to help international colleagues build vital maritime security capacity. CCMR has been teaching seminars and workshops on fighting terrorism for civilian and military officials from more than 145 countries since 2002. We now use Fighting Back as a standard reference work for all those courses; it is our intent to use this book in the same way - to help other governments develop a broad and deep understanding of what we call "Maritime Violence." 
Many US government organizations and institutions are involved in helping friendly governments build tactical maritime security capacity, but programs targeting the strategic level of decision-making are in short supply. Operational assistance to our maritime colleagues is definitely a good thing, but most governments need even more help at the national and regional levels. Virtually every maritime security threat is transnational, and some of them reside on the high seas. Lasting maritime security requires the cooperation of national institutions, regional partners, and maritime nations from all over the world. Leaving the treatment of interstate conflict to other authors, we focus on an array of challenges to maritime security requiring international cooperation: maritime terrorism, piracy, sea robbery, maritime smuggling, and port security. Our title comes from the rubric we have been using to link these activities together; each of them features, or benefits from, maritime violence.

Three factors complicate a government's efforts to maintain security in the maritime domain. The first is imposed by international law, the second by institutional roles, and the third by limited resources. Governance in maritime areas brings all these considerations together, not always smoothly, adding complexity to an already difficult problem. International law has shaped each nation's maritime space, opening the door to both institutional and international conflicts. National and international institutions clash along the seams that delineate maritime zones, cooperating where they can, but competing for resources where they must. No government has enough resources to protect everything, especially in the global maritime domain through which most of the world's trade must pass. Territorial seas and exclusive economic zones are difficult; the high seas are much harder. Where does one even start?

We started with teaching, and now we are ready to write the book. This is more than an edited volume; it reflects the complex cross-cutting classroom discussions we have engaged in collectively with our international colleagues. Despite the ambiguities, a few things are clear. States need to govern their maritime spaces better and invest more in developing maritime security capacity. National institutions must work as a team, and governments around the world will have to find ways to cooperate for the common good. In this book, we hope to advance a number of practical ideas that governments can use to protect their societies against maritime threats, meet the difficulties that arise, and peacefully exploit the opportunities that lie alongside those challenges. 